\title{
Plankton metabolism in surface waters of the tropical and subtropical Pacific Ocean
}

\author{
Donn A. Viviani, Karin M. Björkman, David M. Karl, Matthew J. Church* \\ Department of Oceanography, University of Hawaii, Honolulu, Hawaii 96822, USA
}

\begin{abstract}
We measured plankton metabolism and evaluated changes in plankton community structure within the central Pacific Ocean during a trans-equatorial cruise from the South Pacific Subtropical Gyre (SPSG) to the North Pacific Subtropical Gyre (NPSG). Rates of net community production (NCP) and respiration $(\mathrm{R})$ were determined in near-surface ocean waters, based on light-dark bottle measurements of oxygen production and consumption. Gross primary production (GPP) was computed, where GPP = NCP + R. Rates of GPP and R in the oligotrophic SPSG and NPSG were tightly coupled, resulting in NCP that was either zero or slightly negative. These subtropical waters were characterized by very low concentrations of inorganic nutrients (e.g. nitrate+nitrite range: 0.004 to 0.033 $\mu \mathrm{mol} \mathrm{l}^{-1}$ ). Within the relatively nutrient-enriched equatorial waters (e.g. nitrate+nitrite concentrations range: 0.67 to $\left.5.7 \mathrm{~mol} \mathrm{l}^{-1}\right)$, GPP exceeded R by up to 5 -fold, resulting in positive NCP. GPP varied $\sim 16$-fold $(0.25$ to $4.05 \mu \mathrm{mol} \mathrm{O}_{2}$ produced $\mathrm{l}^{-1} \mathrm{~d}^{-1}$ ) while $\mathrm{R}$ varied $\sim 5$-fold (0.31 to $1.56 \mu \mathrm{mol} \mathrm{O} \mathrm{O}_{2}$ consumed $\mathrm{l}^{-1} \mathrm{~d}^{-1}$ ). Picoplankton cell abundances and diagnostic pigment biomarkers were used to determine regional differences in phytoplankton community structure. In the near-equatorial waters, abundances of Synechococcus and photosynthetic picoeukaryotes increased up to 100- and 10-fold, respectively, and diagnostic pigment biomarkers for eukaryotic phytoplankton (including diatoms, pelagophytes, and haptophytes) also increased. These results indicate that variability in nutrient availability constitutes an important regulator of net productivity and plankton community structure in large regions of the open ocean.
\end{abstract}

KEY WORDS: Gross primary production - Respiration • Net community production . Equatorial Pacific . Subtropical gyres

Resale or republication not permitted without written consent of the publisher

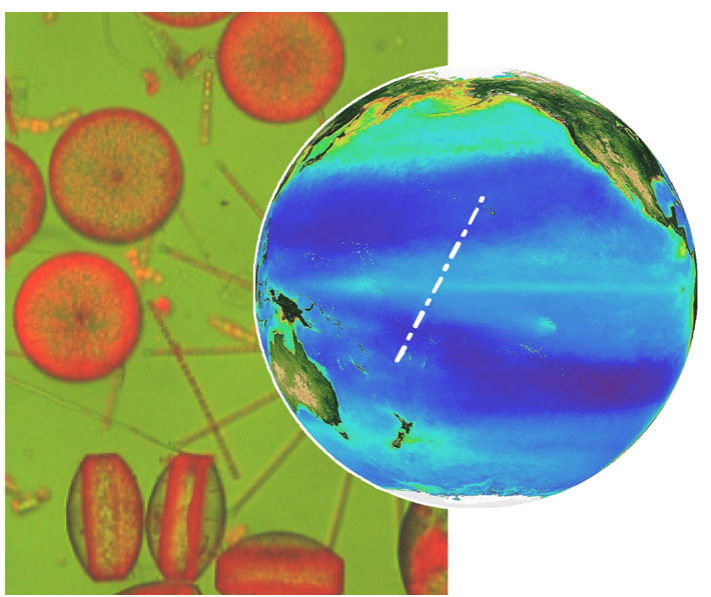

Satellite (SeaWiFS) ocean color image of the Pacific Ocean superimposed on a diatom assemblage viewed by epifluorescence microscopy. Cruise track occupied during this study depicted by the white dashed line on the SeaWiFS image.

Ocean color image: NASA; diatom photo: Rachel Foster

\section{INTRODUCTION}

Photosynthetic ocean plankton account for approximately half of the total oxygen production and carbon fixation on Earth (Falkowski 1994), and a major fraction of this productivity occurs in the oligotrophic gyres that encompass $\sim 40 \%$ of the planet's surface area (Field et al. 1998). Biomass and metabolism in oceanic ecosystems are dominated by planktonic microorganisms and the activities of these microorganisms control the net balance between carbon fixation and respiration (Duarte \& Cebrian 1996, Falkowski et al. 2008). Throughout much of the world's oceans, gross primary production (GPP) and plankton community respiration (R) are tightly coupled in space and time; the balance 
between these 2 ecosystem processes is termed net community production (NCP). Small changes in NCP, favoring either net production or net respiration, can have large consequences on the carbon and oxygen storage potentials of the ocean (del Giorgio \& Duarte 2002). As a result, it is vital to understand the temporal and spatial scales over which oxygenic photosynthesis is coupled to $\mathrm{R}$.

In vast regions of the oceans, rates of primary production are limited by the supply of inorganic nutrients to the well-lit regions of the euphotic zone. Despite low nutrient concentrations, various lines of evidence suggest microorganism growth rates in these systems are near maximal (Goldman et al. 1979, Laws et al. 1987); presumably maintained in large part by active recycling of nutrients (Azam et al. 1983, Goldman 1988). Other studies argue that the low nutrient conditions observed throughout large regions of the world's oceans restrict plankton growth rates (Marañón 2005).

In the past decade, there has been considerable controversy over the metabolic state of these oligotrophic regions. Numerous geochemical approaches, typically integrating estimates of production and respiration over weekly to monthly time scales, suggest ocean ecosystems are slightly net autotrophic, demonstrating positive NCP, and therefore capable of supporting carbon export to the deep sea (Jenkins \& Goldman 1985, Siegenthaler \& Sarmiento 1993, Carlson et al. 1994, Michaels et al. 1994, Emerson et al. 1997, Luz \& Barkan 2000, Emerson et al. 2002, Karl et al. 2003, Riser \& Johnson 2008). Other studies, relying on incubation experiments to measure biological oxygen production and consumption over hourly to daily time scales, often demonstrate that oligotrophic ocean ecosystems are significantly net heterotrophic, whereby organic matter and oxygen are consumed more rapidly than locally produced (del Giorgio et al. 1997, Duarte \& Agusti 1998, Serret et al. 2001, del Giorgio \& Duarte 2002, Robinson et al. 2002, Williams et al. 2004). To date, it remains unclear why these various measures of plankton metabolism provide fundamentally different conclusions regarding the net metabolic state of the sea.

In the present study, we sought to examine spatial variability in rates of GPP, NCP, and R in the nearsurface waters of remote regions in the Pacific Ocean. We report results obtained from a trans-equatorial research cruise through biogeochemically distinct regions of the tropical and subtropical Pacific Ocean between $16^{\circ} \mathrm{S}$ and $22.75^{\circ} \mathrm{N}$. By evaluating plankton metabolism relative to distributions of nutrients and planktonic microorganisms, the resulting data provide insight into the coupling between nutrient availability, plankton biomass, and alterations in phytoplankton community structure as factors controlling the net metabolism of the Pacific Ocean.

\section{MATERIALS AND METHODS}

Sampling scheme, determinations of nutrients, pigments, and adenosine-5'-triphosphate concentrations. All sampling took place between $\sim 16^{\circ} \mathrm{S}$ and $22.75^{\circ} \mathrm{N}$ aboard the RV 'Kilo Moana' in April and May 2007 (Fig. 1). Metabolic rate measurements were conducted at 13 stations. At 12 of these stations, seawater for assessment of metabolic rates was collected from the ship's uncontaminated flow-through seawater intake system $(\sim 7 \mathrm{~m}$ depth); at the northern-most station $\left(22.75^{\circ} \mathrm{N}, 158^{\circ} \mathrm{W}\right)$, seawater was collected from $5 \mathrm{~m}$ depth using a conductivity-temperature-density (CTD) rosette sampler equipped with $10 \mathrm{l}$ polyvinyl chloride bottles. In addition, at 8 stations, samples were collected from vertical profiles using a CTD rosette system to characterize upper ocean (0 to $200 \mathrm{~m}$ ) biogeochemistry (e.g. nutrient, particulate matter, and pigment con-

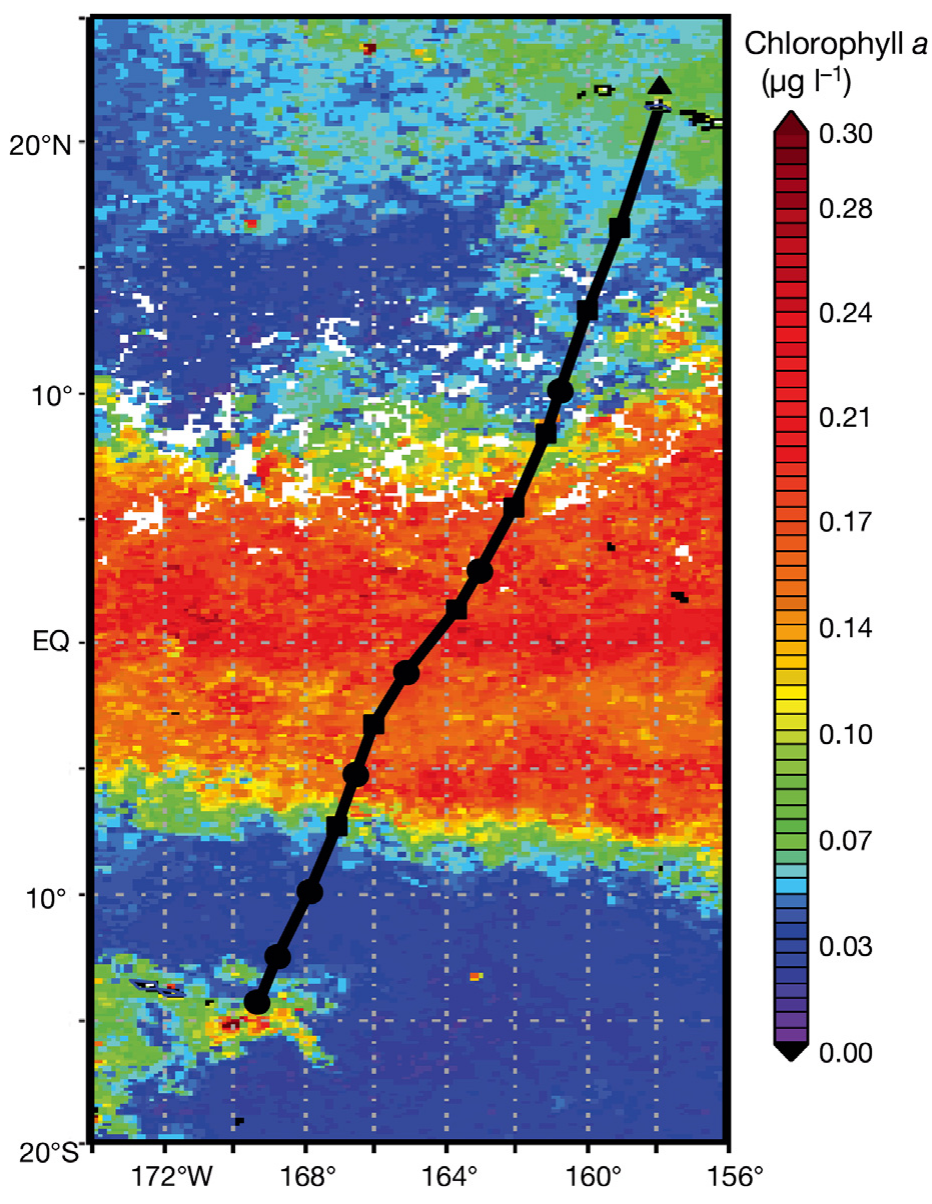

Fig. 1. Cruise transect (black line) with stations for metabolic rate measurements in the Pacific Ocean plotted on a map of near-surface ocean chlorophyll a concentrations in April 2007 (Acker \& Leptoukh 2007) derived from MODIS satellite ocean color. : stations where samples were collected from nearsurface waters; $\square$ : stations where CTD vertical profiles were conducted; $\boldsymbol{\Delta}$ : Station ALOHA $\left(22.75^{\circ} \mathrm{N}, 158^{\circ} \mathrm{W}\right)$ 
centrations) along the cruise transect. Seawater samples for determination of nutrient concentrations (nitrate+nitrite, $\mathrm{N}+\mathrm{N}$; soluble reactive phosphorus, SRP; and silicic acid, $\mathrm{Si}(\mathrm{OH})_{4}{ }^{-2}$ ) were collected in 125 or $500 \mathrm{ml}$ acid-washed polyethylene bottles and frozen upright for analysis in the shore-based laboratory. N+N concentrations were measured using the high sensitivity chemiluminescent technique (Garside 1982, Dore \& Karl 1996), which has a detection limit of $\sim 2 \mathrm{nmol} \mathrm{l}^{-1}$. SRP samples were analyzed using the magnesium-induced co-precipitation method (MAGIC; Karl \& Tien 1992), which has a detection limit of $\sim 3 \mathrm{nmol}^{-1}$. $\mathrm{Si}(\mathrm{OH})_{4}{ }^{-2}$ concentrations were measured in a $10 \mathrm{~cm}$ cell using the molybdate blue spectrophotometric technique described by Strickland \& Parsons (1972), which has a detection limit of $\sim 0.1 \mu \mathrm{mol} \mathrm{l}^{-1}$.

Seawater samples for HPLC determination of phytoplankton pigment concentrations were collected in $4 \mathrm{l}$ carboys, filtered onto $25 \mathrm{~mm}$ glass-fiber filters (GF/F, Whatman), flash frozen in liquid nitrogen and then stored at $-80^{\circ} \mathrm{C}$. Once on land, pigments were analyzed as in Bidigare et al. (2005). Seawater samples for subsequent quantification of cellular adenosine-5'triphosphate (ATP) concentrations were pre-filtered through a $202 \mu \mathrm{m}$ Nitex mesh to exclude zooplankton, and collected into acid-washed 41 polyethylene bottles. Of these subsamples, 11 was vacuum filtered onto $47 \mathrm{~mm} \mathrm{GF} / \mathrm{F}$ filters (Whatman); filters were placed in Vacutainer (Becton Dickinson) test tubes containing $5 \mathrm{ml}$ boiling Tris buffer ( $\mathrm{pH} 7.4,0.02 \mathrm{M}$ ) and extracted for $5 \mathrm{~min}$, then frozen until analyzed at the shore-based laboratory. ATP concentrations were quantified as in Karl \& Holm-Hansen (1978). Samples for quantification of particulate carbon (PC) concentrations were collected in $10 \mathrm{l}$ carboys, pre-filtered through a $202 \mu \mathrm{m}$ Nitex mesh to exclude large zooplankton and collected onto combusted 25 mm GF/F glass-fiber filters. Carbon and nitrogen concentrations were determined by combustion using an Exeter CE440 Elemental Analyzer.

Measurements of plankton metabolism. Determinations of GPP, NCP and R were based on light-dark bottle oxygen production and consumption measurements (Carritt \& Carpenter 1966, Williams et al. 2004). These measurements provided estimates of NCP, the balance of oxygen produced and consumed in the light bottle incubations relative to a time zero; $\mathrm{R}$, total oxygen consumption in the dark bottle incubation relative to a time zero; and GPP, calculated as NCP + R, which constrains the total oxygen production inclusive of respiratory losses. Metabolic rate measurements were conducted from near-surface waters at 13 stations. Rates are reported as changes in $\mathrm{O}_{2}$ concentration per liter per day.

Seawater for rate determinations was collected into $25 \mathrm{l}$ carboys, and replicate $125 \mathrm{ml}$ borosilicate flasks were subsampled from the carboys. At each sampling, 8 replicate time-zero bottles were immediately fixed with Winkler oxygen reagents, 8 replicate bottles were filled and incubated under simulated in situ irradiance, and 8 replicates were placed in opaque containers and incubated in the dark. At 12 stations, bottles were incubated for $24 \mathrm{~h}$ in shipboard surface seawater flowthrough incubators shaded with blue Plexiglas screening to $\sim 30 \%$ incident irradiance. At the northern-most station $\left(22.75^{\circ} \mathrm{N}, 158^{\circ} \mathrm{W}\right)$ bottles were incubated in situ for $24 \mathrm{~h}$ on a free-drifting surface tethered array as described in Williams et al. (2004); we did not directly compare rates measured on the in situ array to those determined by shipboard incubations.

Picoplankton community structure. Cellular abundance and composition of the picoplankton assemblage were determined using flow cytometry. For these determinations, seawater was sampled from the CTD rosette bottles into $15 \mathrm{ml}$ polyethylene centrifuge tubes; $2 \mathrm{ml}$ were subsampled into $2 \mathrm{ml}$ Cryovials and fixed with $30 \mu \mathrm{l}$ of $16 \%$ paraformaldehyde, immediately flash-frozen in liquid nitrogen and stored at $-80^{\circ} \mathrm{C}$ until shore-based analysis. In the laboratory, samples were thawed and counted on a Cytopeia Influx Mariner flow cytometer using a $488 \mathrm{~nm}$ solidstate laser for excitation, triggering on forward scatter. The enumeration and fluorescence data were analyzed using FlowJo software (Tree Star, www.flowjo.com). Forward light scatter (FLS), red fluorescence (692 nm) and orange fluorescence $(580 \mathrm{~nm})$ were detected and quantified. Populations were enumerated by double discrimination of flow cytometry-derived characteristics. Specifically, abundances of non-pigmented picoplankton (hereafter referred to as heterotrophic bacteria) were determined based on SyberGreen I (Molecular Probes) stained total cell abundances following subtraction of unstained Prochlorococcus cell counts. Chlorophyll-containing cells were broadly classified into one of 3 groups (Prochlorococcus, Synechococcus, and picoeukaryotes) based on FLS and relative fluorescence. Synechococcus was further distinguished by orange fluorescence. Picoeukaryotes were differentiated from the relatively smaller cyanobacteria by greater FLS and red fluorescence.

\section{RESULTS}

\section{Upper ocean hydrography and nutrient concentrations}

Samples were collected within biogeochemically distinct regions of the subtropical and tropical Pacific, including the low-nutrient waters of the subtropical North and South Pacific, and the relatively nutrient-enriched 
waters in the equatorial divergence. Measurements of plankton metabolism were conducted at 4 stations sampled in the Western Pacific Warm Pool of the South Pacific Subtropical Gyre (SPSG). The near-surface ocean waters within this region were characterized by warm sea surface temperatures (SST $>28^{\circ} \mathrm{C}$ ), elevated salinity, and low concentrations of inorganic nutrients (concentrations of $\mathrm{N}+\mathrm{N} \leq 0.033 \mu \mathrm{mol} \mathrm{l}^{-1}$, SRP $\leq 0.18 \mu \mathrm{mol}$ $\mathrm{l}^{-1}$, and $\mathrm{Si}(\mathrm{OH})_{4}{ }^{-2} \leq 0.77 \mu \mathrm{mol} \mathrm{l}^{-1}$; Table 1). A total of 6 stations were sampled in the near-equatorial region where the upper ocean exhibited features consistent with upwelling of cooler, nutrient-enriched waters (Fig. 2). Between $5^{\circ} \mathrm{S}$ and $10^{\circ} \mathrm{N}$, near-surface concentrations of $\mathrm{N}+\mathrm{N}$ were as much as 2 orders of magnitude greater $\left(>3 \mu \mathrm{mol} \mathrm{l^{-1 }}\right.$ ) than those observed in the subtropical gyres, while concentrations of SRP and $\mathrm{Si}(\mathrm{OH})_{4}^{-2}$ increased by as much as 3 -fold (maximal values of $0.45 \mu \mathrm{mol} \mathrm{l}^{-1}$ and $2.06 \mu \mathrm{mol} \mathrm{l}^{-1}$, respectively; Table 1). North of the equatorial divergence, nearsurface nutrient concentrations decreased to concentrations typical of the North Pacific Subtropical Gyre (NPSG). A total of 3 stations were sampled in these waters in which near-surface $\mathrm{N}+\mathrm{N}, \mathrm{SRP}$, and $\mathrm{Si}(\mathrm{OH})_{4}{ }^{-2}$ concentrations were $\leq 0.01 \mu \mathrm{mol} \mathrm{l}^{-1}, \leq 0.13 \mu \mathrm{mol} \mathrm{l}^{-1}$, and $\leq 1.97 \mu \mathrm{mol}^{-1}$, respectively.

\section{Phytoplankton pigments, particulate carbon, and picoplankton community structure}

Consistent with the observed meridional changes in upper ocean hydrography and nutrients, concentra-

Table 1. Near-surface ocean measurements of nutrient concentrations at stations sampled for metabolic balance measurements. N(S)PSG: North (South) Pacific Subtropical Gyre, N+N: nitrate+nitrite, SRP: soluble reactive phosphorus

\begin{tabular}{|lccc|}
\hline $\begin{array}{l}\text { Region and } \\
\text { station location }\end{array}$ & $\begin{array}{c}\mathrm{N}+\mathrm{N} \\
\left(\mu \mathrm{mol} \mathrm{l}^{-1}\right)\end{array}$ & $\begin{array}{c}\mathrm{SRP} \\
\left(\mu \mathrm{mol} \mathrm{l}^{-1}\right)\end{array}$ & $\begin{array}{c}\mathrm{Si}(\mathrm{OH})_{4}^{-2} \\
\left(\mu \mathrm{mol}^{-1}\right)\end{array}$ \\
\hline $\mathbf{S P S G}$ & & & \\
$14.3^{\circ} \mathrm{S}, 169.2^{\circ} \mathrm{W}$ & 0.027 & 0.122 & 0.62 \\
$12.5^{\circ} \mathrm{S}, 168.7^{\circ} \mathrm{W}$ & 0.033 & 0.134 & 0.56 \\
$9.9^{\circ} \mathrm{S}, 167.8^{\circ} \mathrm{W}$ & 0.026 & 0.153 & 0.77 \\
$7.3^{\circ} \mathrm{S}, 167.0^{\circ} \mathrm{W}$ & 0.006 & 0.175 & 0.69 \\
Equatorial & & & \\
$5.2^{\circ} \mathrm{S}, 166.5^{\circ} \mathrm{W}$ & 0.67 & 0.251 & 1.10 \\
$3.3^{\circ} \mathrm{S}, 166.0^{\circ} \mathrm{W}$ & 4.62 & 0.393 & 1.82 \\
$1.2^{\circ} \mathrm{S}, 165.1^{\circ} \mathrm{W}$ & 3.51 & 0.371 & 1.57 \\
$1.4^{\circ} \mathrm{N}, 163.6^{\circ} \mathrm{W}$ & 5.66 & 0.450 & 2.06 \\
$5.5^{\circ} \mathrm{N}, 162.0^{\circ} \mathrm{W}$ & 2.91 & 0.174 & 1.76 \\
$8.4^{\circ} \mathrm{N}, 161.1^{\circ} \mathrm{W}$ & 0.90 & 0.170 & 1.10 \\
$\mathbf{N P S G}^{\circ} \mathrm{M}$ & & & \\
$13.3^{\circ} \mathrm{N}, 160.0^{\circ} \mathrm{W}$ & 0.009 & 0.132 & 1.97 \\
$16.5^{\circ} \mathrm{N}, 159.0^{\circ} \mathrm{W}$ & 0.006 & 0.104 & 1.16 \\
$22.8^{\circ} \mathrm{N}, 158.0^{\circ} \mathrm{W}$ & 0.004 & 0.095 & 0.95 \\
\hline
\end{tabular}

tions of chlorophyll a ( $\mathrm{chl}$ a) also demonstrated strong regional differences. In the NPSG and SPSG, chl a concentrations in the near-surface waters were low $\left(<90 \mathrm{ng} \mathrm{l}^{-1}\right)$, increasing into the dimly-lit regions of the upper ocean (Fig. 2). In contrast, in the near-surface equatorial waters, concentrations of chl a increased more than 6-fold (range: 155 to $294 \mathrm{ng} \mathrm{l}^{-1}$ ) relative to those measured in the subtropical gyres (Fig. 2, Table 2). Particulate carbon (PC) varied from 1.7 to

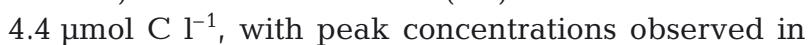
the southern equatorial waters $\left(3\right.$ to $\left.5^{\circ} \mathrm{S}\right)$. Concentrations of particulate ATP, a proxy for total cellular biomass, tended to be low (range: 20 to $39 \mathrm{ng} \mathrm{l}^{-1}$ ) in the near-surface waters in the SPSG and NPSG, increasing by up to 2 -fold in the equatorial waters (Table 2 ).

Flow cytometric enumeration of picoplankton revealed that Prochlorococcus were consistently the most abundant chlorophyll-containing cells in all regions sampled (Fig. 3). Prochlorococcus abundances

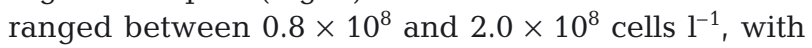
cell abundances decreasing from subtropical gyres to near-equatorial waters. Upper ocean concentrations of Synechococcus and phototrophic picoeukaryotes in the SPSG and NPSG were low or not detected (Fig. 3), with abundances of both groups increasing by more than 100- and 10-fold, respectively, in the nearequatorial waters (Fig. 3). Synechococcus and picoeukaryote together accounted for a small fraction (1 to $8 \%$ ) of photosynthetic picoplankton abundance in the subtropical gyres; however, their relative contributions increased to $13 \%$ in the near-equatorial waters (Fig. 3). These changes in the partitioning of picoplankton in the equatorial region were driven by large increases in Synechococcus and picoeukaryote abundance superimposed on modest decreases in Prochlorococcus abundances. Although Prochlorococcus cell abundances decreased slightly in the nearequatorial waters, relative fluorescence associated with these cells increased more than 3 -fold in the $\mathrm{N}+\mathrm{N}$ enriched waters of the equatorial region (Fig. 4). Moreover, flow cytometric measurements of Prochlorococcus cell FLS, a proxy for cell size, also increased in the near-equatorial waters (Fig. 4). On average, heterotrophic bacterial abundances varied less than 2 -fold between subtropical gyres and equatorial waters (averaging $3.9 \times 10^{8}$ cells $^{-1}$ compared to $6.3 \times$

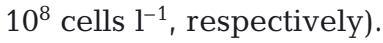

Analyses of HPLC phytoplankton pigment concentrations provided additional information on regional variations in phytoplankton community structure. Concentrations of pigments that serve as biomarker proxies for various classes of eukaryotic phytoplankton increased in the near-equatorial waters (Table 2). Relative to concentrations of total $\mathrm{chl} a$, the carotenoid pigments 19'-butanoyloxyfucoxanthin (a biomarker 


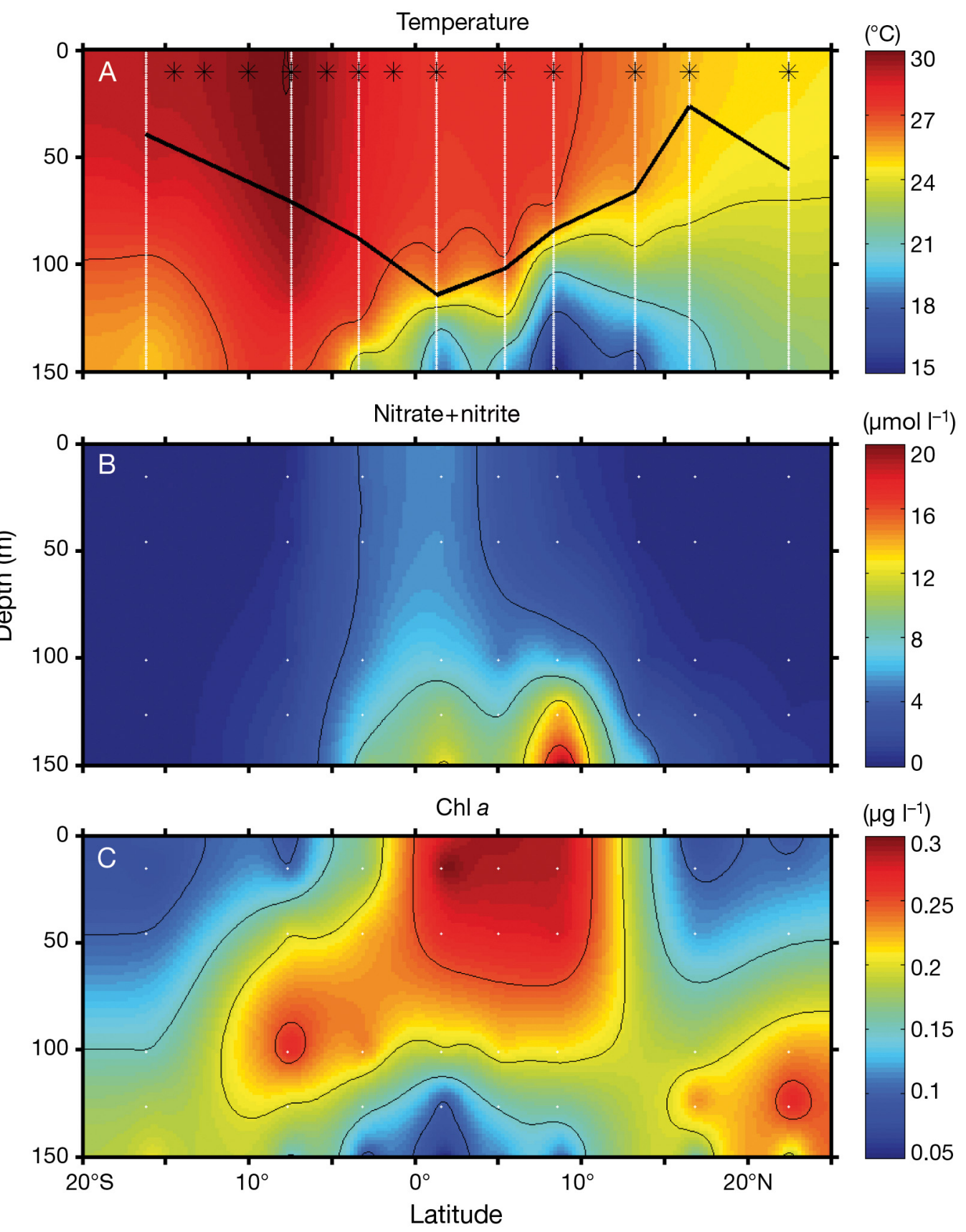

Fig. 2. Contour plots depicting latitudinal variation in (A) upper ocean (0 to $150 \mathrm{~m}$ ) temperature, (B) concentrations of nitrate + nitrite and (C) chlorophyll (chl) a. White dotted lines represent stations where vertical profiles were collected, while black asterisks depict stations sampled for metabolic rate measurements. Solid black line depicts regional changes in the depth of the mixed layer determined based on a 0.125 unit change in potential density

proxy for pelagophytes), 19'-hexanoyloxyfucoxanthin (a biomarker proxy for prymnesiophytes), and fucoxanthin (a biomarker proxy for diatoms) all increased in the northern regions of the near-equatorial waters (Fig. 5). Despite decreases in Prochlorococcus cell abundances, concentrations of divinyl chl $a$, a diagnostic pigment for Prochlorococcus, increased in the equa- torial waters (Table 2). This observation is consistent with the apparent increases in the relative per cell fluorescence of Prochlorococcus (Fig. 3); normalization of divinyl chl a concentrations to Prochlorococcus cell abundances revealed up to 5 -fold increases in the pigmentation of Prochlorococcus in the northern equatorial waters. 
Table 2. Regional distributions of near-surface ocean phytoplankton pigments, particulate carbon (PC), and ATP. Pigments include divinyl chlorophyll a (Dv Chl), and the carotenoid pigments 19'butanoyloxyfucoxanthin (19-But), 19'-hexanoyloxyfucoxanthin (19-Hex), and fucoxanthin (Fuco). N(S)PSG: North (South) Pacific Subtropical Gyre, bd: below detection limit, nd: no data available

\begin{tabular}{|c|c|c|c|c|c|c|c|}
\hline $\begin{array}{l}\text { Region and } \\
\text { station location }\end{array}$ & $\begin{array}{c}\text { PC } \\
\left(\mu \mathrm{mol} \mathrm{C} \mathrm{^{-1 }}\right)\end{array}$ & $\begin{array}{c}\text { ATP } \\
\left(\mathrm{ng} \mathrm{l}^{-1}\right)\end{array}$ & $\begin{array}{c}\text { Chl a } \\
\left(\mathrm{ng} \mathrm{l}^{-1}\right)\end{array}$ & $\begin{array}{l}\text { Dv Chl } \\
\left(\mathrm{ng} \mathrm{l}^{-1}\right)\end{array}$ & $\begin{array}{l}\text { 19-But } \\
\left(\mathrm{ng} \mathrm{l}^{-1}\right)\end{array}$ & $\begin{array}{l}\text { 19-Hex } \\
\left(\mathrm{ng} \mathrm{l}^{-1}\right)\end{array}$ & $\begin{array}{l}\text { Fuco } \\
\left(\mathrm{ng} \mathrm{l}^{-1}\right)\end{array}$ \\
\hline \multicolumn{8}{|l|}{ SPSG } \\
\hline $14.3 \mathrm{~S}, 169.2^{\circ} \mathrm{W}$ & 2.7 & 37 & 73 & 26 & 1.4 & 8.5 & bd \\
\hline $12.5 \mathrm{~S}, 168.7^{\circ} \mathrm{W}$ & 2.7 & 25 & 46 & 22 & 1.3 & 7.0 & $\mathrm{bd}$ \\
\hline $9.9 \mathrm{~S}, 167.8^{\circ} \mathrm{W}$ & 3.5 & 21 & 45 & 24 & 1.3 & 9.2 & $\mathrm{bd}$ \\
\hline $7.3 \mathrm{~S}, 167.0^{\circ} \mathrm{W}$ & 1.7 & nd & 64 & 39 & 2.6 & 12 & 1.3 \\
\hline \multicolumn{8}{|l|}{ Equatorial } \\
\hline $5.2 \mathrm{~S}, 166.5^{\circ} \mathrm{W}$ & 4.4 & 25 & 210 & 110 & 8.9 & 47 & 8.0 \\
\hline $3.3 \mathrm{~S}, 166.0^{\circ} \mathrm{W}$ & 4.0 & 73 & 161 & 67 & 13 & 49 & 7.6 \\
\hline $1.2 \mathrm{~S}, 165.1^{\circ} \mathrm{W}$ & 3.4 & 24 & 155 & 71 & 12 & 41 & 9.4 \\
\hline $1.4 \mathrm{~N}, 163.6^{\circ} \mathrm{W}$ & 2.8 & 74 & 261 & 93 & 34 & 72 & 16 \\
\hline $5.5 \mathrm{~N}, 162.0^{\circ} \mathrm{W}$ & 3.3 & 39 & 294 & 112 & 34 & 87 & 15 \\
\hline $8.4 \mathrm{~N}, 161.1^{\circ} \mathrm{W}$ & 2.6 & 60 & 293 & 144 & 33 & 78 & 11 \\
\hline \multicolumn{8}{|l|}{ NPSG } \\
\hline $13.3 \mathrm{~N}, 160.0^{\circ} \mathrm{W}$ & nd & 21 & 91 & 53 & 5.2 & 13 & 4.3 \\
\hline $16.5 \mathrm{~N}, 159.0^{\circ} \mathrm{W}$ & 2.0 & 29 & 44 & 20 & 1.4 & 6.2 & 2.1 \\
\hline $22.8 \mathrm{~N}, 158.0^{\circ} \mathrm{W}$ & 2.0 & 34 & 73 & 33 & 3.0 & 11 & 6.0 \\
\hline
\end{tabular}

\section{Plankton community metabolism}

Rates of plankton community metabolism varied considerably among the regions sampled. Overall, rates of GPP in the near-surface ocean varied 16-fold (ranging from 0.25 to $4.05 \mu \mathrm{mol} \mathrm{O}_{2} \mathrm{l}^{-1} \mathrm{~d}^{-1}$ ), with elevated rates observed in the nutrient-enriched waters of the near-equatorial regions and lower rates measured in the oligotrophic gyres (Fig. 6). In contrast, rates of $\mathrm{R}$ were somewhat less variable, ranging 5 -fold $(0.31$ to

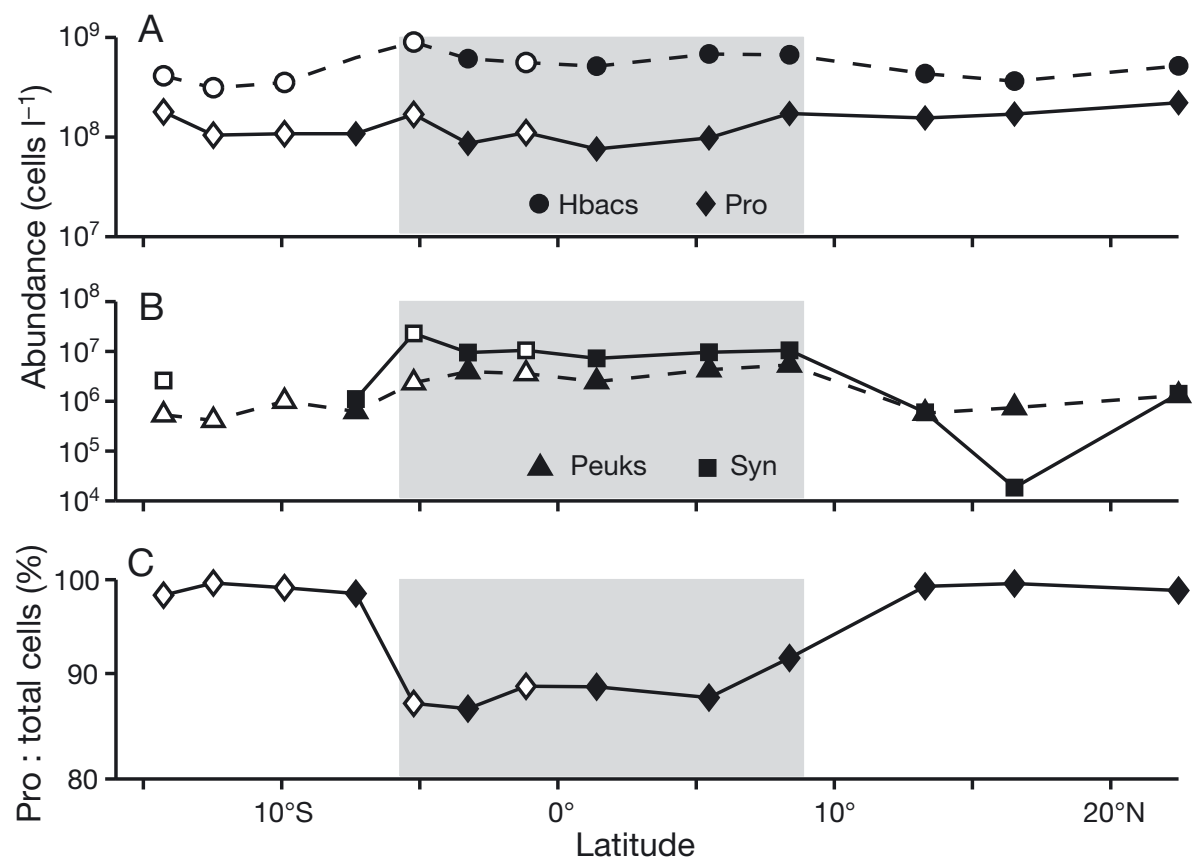

Fig. 3. Latitudinal variations in near-surface ocean picoplankton cell abundances and relative changes in Prochlorococcus. Abundance of (A) heterotrophic bacteria (Hbacs) and Prochlorococcus (Pro) and (B) Synechococcus (Syn) and chlorophyll (chl) a-containing picoeukaryotes (Peuks). (C) Prochlorococcus abundance (Pro, \%) relative to total chl a-containing picoplankton. Samples collected from the uncontaminated seawater system at underway stations are depicted as open symbols, while samples collected from CTD rosette bottles are shown as filled symbols. Shaded areas depict regions where near-surface ocean nitrate+ nitrite concentrations exceeded $0.5 \mu \mathrm{mol} \mathrm{l^{-1 }}$ 

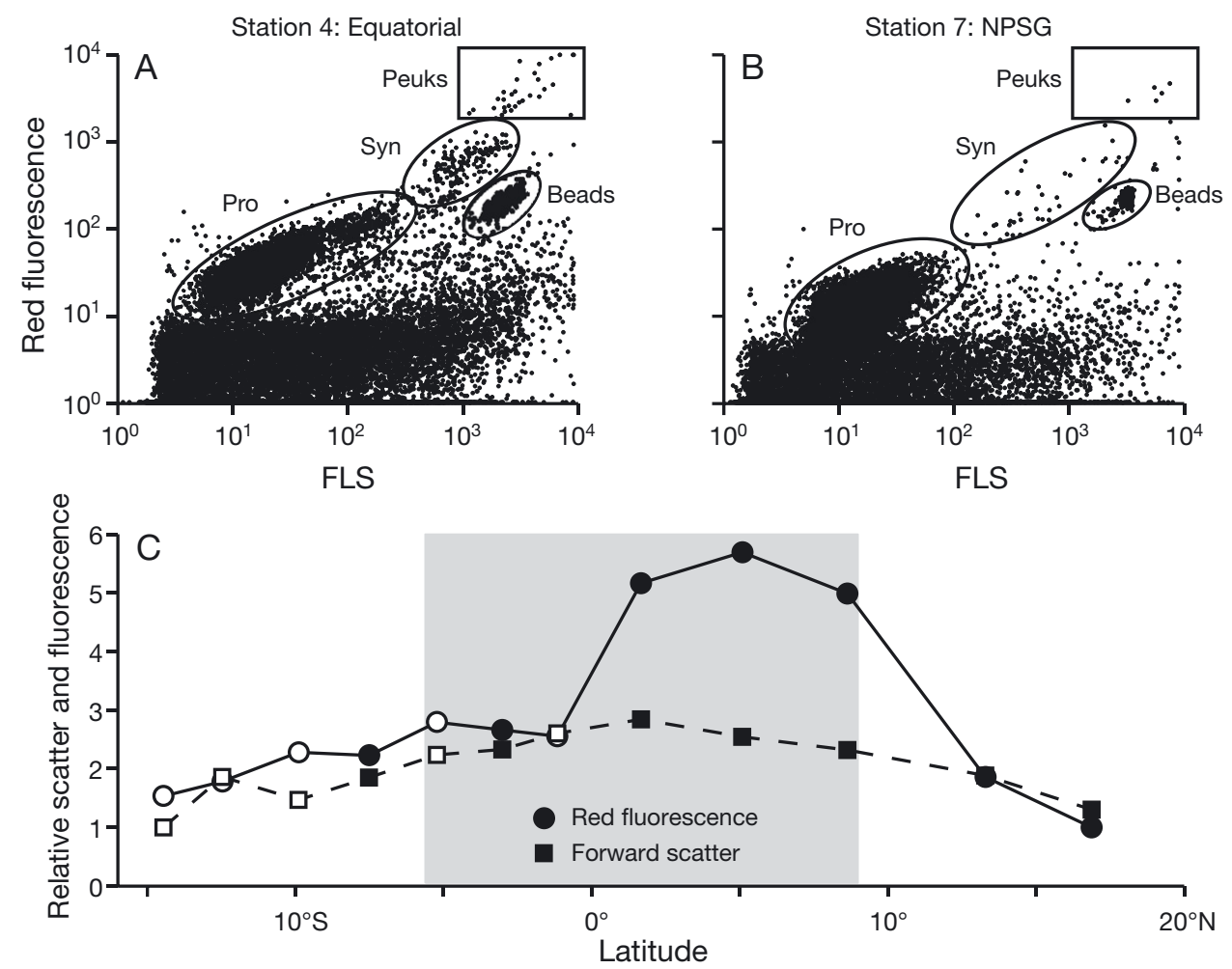

Fig. 4. Scatter plots of red fluorescence and forward light scatter (FLS; excitation by $488 \mathrm{~nm}$ laser) associated with specific groups of pigmented picoplankton at representative stations in (A) near-equatorial and (B) subtropical waters; also shown are $2 \mu \mathrm{m}$ flow cytrometry alignment beads. (C) Flow cytometrically determined variations in relative fluorescence and FLS scatter by populations of Prochlorococcus. Further abbreviations and details as in Fig. 3
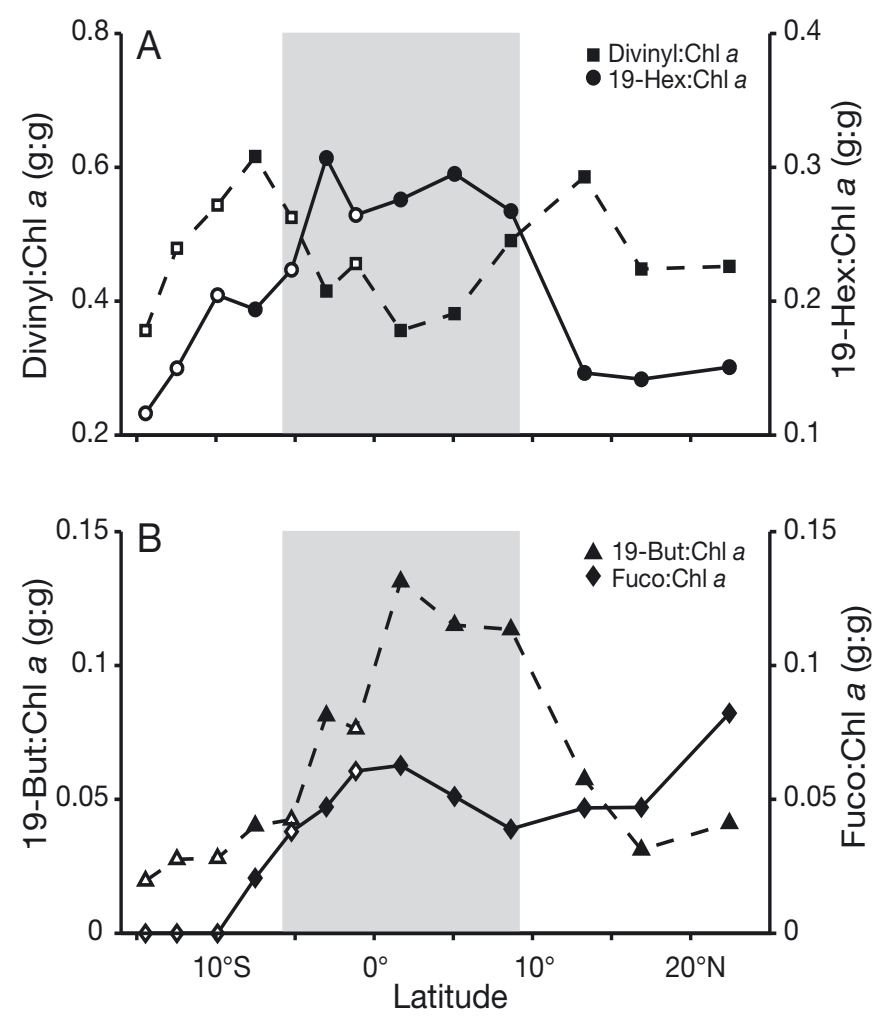

$1.56 \mu \mathrm{mol} \mathrm{O}_{2} \mathrm{l}^{-1} \mathrm{~d}^{-1}$ ). On average, rates of $\mathrm{R}$ were greater in the near-equatorial waters, but there were no statistical differences (1-way ANOVA, $\mathrm{p}>0.05)$ in $\mathrm{R}$ among any of the regions sampled. Rates of NCP varied $\sim 4$-fold, and imbalances in GPP and $\mathrm{R}$ in the nearequatorial waters resulted in positive $\mathrm{NCP}$ in this region (Fig. 6), with rates increasing up to $3.00 \mu \mathrm{mol}$ $\mathrm{O}_{2} \mathrm{l}^{-1} \mathrm{~d}^{-1}$. In contrast, in the low nutrient subtropical gyres, NCP was either statistically indistinguishable from zero or slightly negative (ranging from 0.48 to $-1.31 \mu \mathrm{mol} \mathrm{O} \mathrm{O}_{2} \mathrm{l}^{-1} \mathrm{~d}^{-1}$ ).

In general, NCP was significantly greater than zero (1-way ANOVA, p < 0.05) in those regions where $\mathrm{N}+\mathrm{N}$ concentrations exceeded $0.5 \mathrm{\mu mol} \mathrm{l}^{-1}$, chl a concentra-

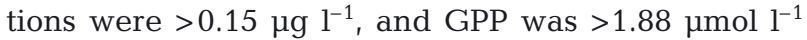
$\mathrm{d}^{-1}$. Rates of chl a-normalized GPP varied $\sim 4$-fold (ranging from 5.2 to $23 \mathrm{~mol} \mathrm{O}_{2}(\mathrm{~g} \mathrm{chl} \mathrm{a})^{-1} \mathrm{~d}^{-1}$; Fig. 6) but on average there were no significant regional differences in these rates (1-way ANOVA, $p>0.05$ ). In con-

Fig. 5. Phytoplankton pigment biomarker distributions. Concentration ratios of (A) divinyl chl $a$ and 19'-hexanoyloxyfucoxanthin (19-Hex) relative to total chl $a$, and (B) 19'butanoyloxyfucoxanthin (19-But) and fucoxanthin (Fuco) relative to total chl a. Shaded regions as in Fig. 3 

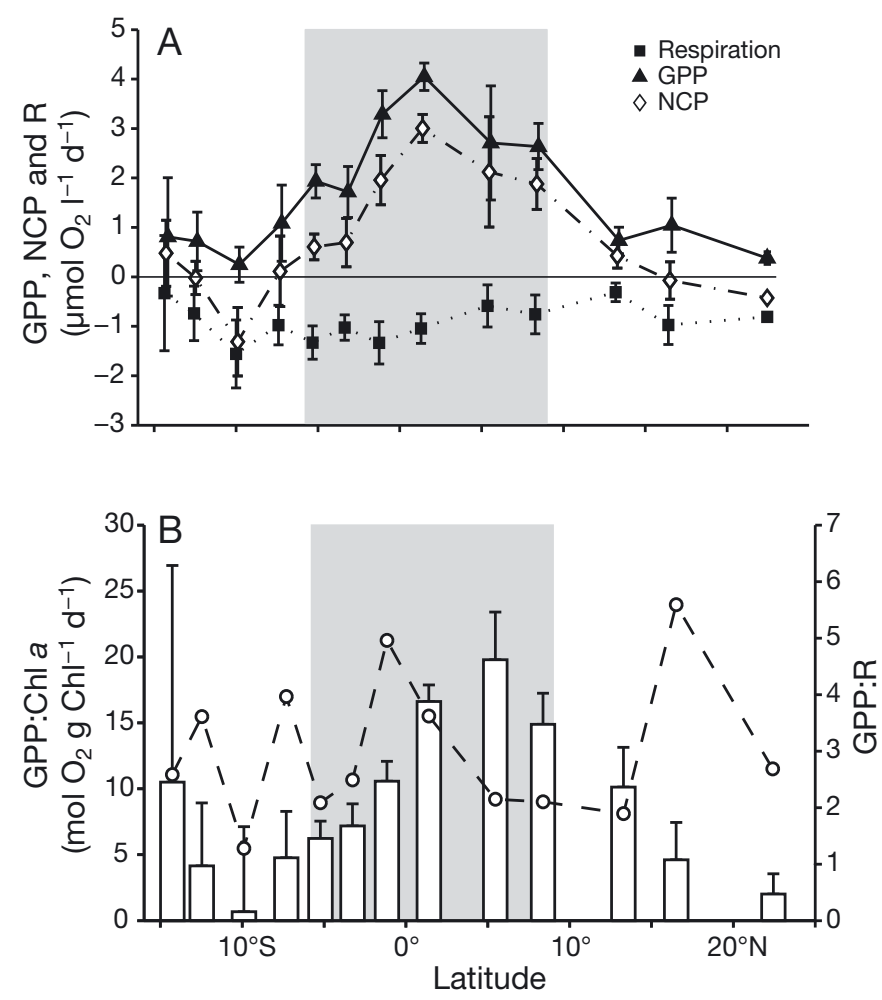

Fig. 6. Latitudinal variations in near-surface ocean plankton metabolism ( $\mu \mathrm{mol} \mathrm{O} \mathrm{O}_{2} \mathrm{l}^{-1} \mathrm{~d}^{-1}$ ). (A) Rates of gross primary production (GPP), net community production (NCP), and respiration (R) at stations sampled along cruise transect. (B) Ratio of GPP:R (open bars) and chlorophyll (chl) a normalized rates of GPP (open circles and dashed line). Shaded areas as in Fig. 3 trast, normalization of GPP to concentrations of particulate carbon revealed more than a 5-fold increase in these carbon-normalized rates in the near-equatorial waters. Correlation analyses indicated a positive relationship between NCP and the abundances of picoeukaryotes (Table 3), as well as concentrations of nutrients and various algal pigments (Table 3). In contrast, only weak relationships were observed between rates of $\mathrm{R}$ and variations in SST, non-pigmented picoplankton, or chl a (Table 3).

\section{DISCUSSION}

Across approximately $5200 \mathrm{~km}$ of the subtropical and tropical Pacific Ocean, we observed strong regional changes in rates of plankton metabolism that coincided with variations in nutrient availability and phytoplankton biomass and community structure. In general, NCP was positive (net autotrophic) in the near-equatorial waters, where rates of GPP were elevated, nutrient concentrations were relatively enriched, and larger phytoplankton comprised a greater fraction of photosynthetic biomass (as observed both by flow cytometry and inferred from increases in eukaryotic phytoplankton pigments). In contrast, NCP appeared closely balanced or slightly negative (net heterotrophic) in the low-nutrient subtropical gyres, where GPP was lower and the picoplanktonic cyanobacteria Prochlorococcus comprised a dominant frac-

Table 3. Correlation matrix depicting relationships between plankton metabolism and biogeochemical properties sampled along the cruise transect. Numbers represent correlation coefficients; abbreviations are temperature (T), respiration (R), net community production $(\mathrm{NCP})$, gross primary production $(\mathrm{GPP})$, nitrate+nitrite $(\mathrm{N}+\mathrm{N})$, soluble reactive phosphorus $(\mathrm{SRP}), \mathrm{Si}(\mathrm{OH})_{4}{ }^{-2}(\mathrm{Si})$, chlorophyll a (chl a), divinyl chlorophyll a (Dv Chl), 19'butanoyloxyfucoxanthin (19-But), 19'-hexanoyloxyfucoxanthin (19-Hex), fucoxanthin (Fuco), adenosine triphosphate (ATP), heterotrophic bacteria (Hbacs), Prochlorococcus (Pro), Synechococcus (Syn), and picoeukaryotes (Peuks)

\begin{tabular}{|c|c|c|c|c|c|c|c|c|c|c|c|c|c|c|c|c|c|}
\hline & $\mathrm{T}$ & $\mathrm{R}$ & $\mathrm{NCP}$ & GPP & $\mathrm{N}+\mathrm{N}$ & SRP & $\mathrm{Si}$ & Chl a & $\begin{array}{l}\mathrm{Dv} \\
\mathrm{Chl}\end{array}$ & $\begin{array}{l}\text { 19- } \\
\text { But }\end{array}$ & $\begin{array}{c}19- \\
\text { Hex }\end{array}$ & Fuco & ATP & Hbacs & Pro & Syn & Peuks \\
\hline $\mathrm{T}$ & 1.00 & & & & & & & & & & & & & & & & \\
\hline $\mathrm{R}$ & -0.35 & 1.00 & & & & & & & & & & & & & & & \\
\hline $\mathrm{NCP}$ & -0.05 & 0.13 & 1.00 & & & & & & & & & & & & & & \\
\hline GPP & 0.04 & -0.18 & 0.95 & 1.00 & & & & & & & & & & & & & \\
\hline $\mathrm{N}+\mathrm{N}$ & 0.05 & -0.23 & 0.75 & 0.82 & 1.00 & & & & & & & & & & & & \\
\hline SRP & 0.25 & -0.44 & 0.64 & 0.76 & 0.92 & 1.00 & & & & & & & & & & & \\
\hline $\mathrm{Si}$ & -0.34 & 0.07 & 0.65 & 0.62 & 0.75 & 0.62 & 1.00 & & & & & & & & & & \\
\hline Chl a & 0.01 & 0.01 & 0.85 & 0.83 & 0.63 & 0.50 & 0.56 & 1.00 & & & & & & & & & \\
\hline Dv Chl & 0.05 & -0.03 & 0.75 & 0.74 & 0.47 & 0.42 & 0.47 & 0.96 & 1.00 & & & & & & & & \\
\hline 19-But & -0.08 & 0.06 & 0.87 & 0.84 & 0.67 & 0.48 & 0.59 & 0.95 & 0.86 & 1.00 & & & & & & & \\
\hline 19-Hex & 0.03 & -0.04 & 0.84 & 0.84 & 0.70 & 0.55 & 0.59 & 0.99 & 0.92 & 0.96 & 1.00 & & & & & & \\
\hline Fuco & -0.21 & -0.04 & 0.87 & 0.88 & 0.76 & 0.61 & 0.73 & 0.93 & 0.83 & 0.92 & 0.93 & 1.00 & & & & & \\
\hline ATP & -0.02 & 0.04 & 0.58 & 0.55 & 0.72 & 0.60 & 0.45 & 0.58 & 0.46 & 0.67 & 0.63 & 0.60 & 1.00 & & & & \\
\hline Hbacs & 0.14 & -0.17 & 0.46 & 0.50 & 0.32 & 0.36 & 0.31 & 0.75 & 0.82 & 0.51 & 0.70 & 0.64 & 0.26 & 1.00 & & & \\
\hline Pro & -0.55 & 0.32 & -0.35 & -0.44 & -0.65 & -0.63 & -0.37 & -0.23 & -0.11 & -0.33 & -0.34 & -0.27 & -0.34 & 0.06 & 1.00 & & \\
\hline Syn & 0.24 & -0.30 & 0.50 & 0.59 & 0.41 & 0.51 & 0.30 & 0.72 & 0.78 & 0.47 & 0.67 & 0.60 & 0.23 & 0.95 & -0.04 & 1.00 & \\
\hline Peuks & 0.00 & -0.14 & 0.68 & 0.72 & 0.61 & 0.50 & 0.48 & 0.86 & 0.85 & 0.81 & 0.89 & 0.79 & 0.57 & 0.69 & -0.21 & 0.65 & 1.00 \\
\hline
\end{tabular}


tion of photosynthetic biomass. These results suggest that both nutrient availability and the nature and structure of plankton food webs play important roles in shaping the net productivity of the sea.

The present study provides insight into how regional changes in phytoplankton community structure (taxa composition and biomass) map onto variations in plankton community metabolism in near-surface waters of the Pacific Ocean. Although Prochlorococcus dominated the chl a-containing picoplankton in all regions sampled, their relative contributions to total photosynthetic picoplankton abundances decreased from $~ 99 \%$ in the subtropical gyres to $~ 85 \%$ in equatorial waters. Further insight into regional differences in the composition of phytoplankton taxa were obtained from analyses of specific phytoplankton pigment biomarkers. In the subtropical gyres, peak concentrations of chl a were observed in the dimly-lit regions of the upper ocean, while chl a concentrations in the equatorial region generally peaked near the ocean's surface. This upward shift in total chl a suggests that phytoplankton biomass increased in the relatively nutrientenriched, near-equatorial waters. Similarly, concentrations of ATP, a proxy for total cellular biomass, also increased by up to 2-fold in the equatorial waters. Coinciding with the observed increases in chl $a$, concentrations of several diagnostic pigments, characteristic of various classes of eukaryotic phytoplankton, also increased in near-equatorial waters. In particular, concentrations of pigments found in pelagophytes, prymnesiophytes, dinoflagellates, chromophytes, and diatoms all increased, suggesting that the relatively nutrient-enriched waters of the equatorial Pacific support a functionally diverse phytoplankton community in which the larger, eukaryotic phytoplankton play an increased role in controlling photosynthetic production.

These findings are consistent with a metagenomic sequencing effort conducted on samples from our cruise (Hewson et al. 2009). Hewson et al. (2009) identified unique spatial partitioning of various Prochlorococcus ecotypes, with near-surface waters of the subtropical gyres dominated by ecotypes most similar to Prochlorococcus strains AS9601, MIT9301, and MIT 9312; ecotypes most similar to strains MIT9515 and CCMP1986 were more prevalent in the near-equatorial waters. These results provide additional evidence that Prochlorococcus speciation broadly maps onto basin-scale ocean physical and biogeochemical features (Bouman et al. 2006, Johnson et al. 2006, Hickman et al. 2010). In addition to meridional changes in Prochlorococcus ecotypes, Hewson et al. (2009) observed variations in Synechococcus population distributions, with distributions of genes most similar to marine Synechococcus strains WH7805 and WH7803 becoming increasingly prevalent in the near-surface waters of the equatorial region. Moreover, the same study noted greater contribution of sequences apparently derived from eukaryotic cells in the equatorial waters than in the subtropical gyres (Hewson et al. 2009). Together, these studies suggest a minor role for Synechococcus and chl a-containing picoeukaryote biomass in the subtropical gyres, but that the contribution of these groups increased markedly in the nutrient-enriched equatorial waters. Intriguingly, despite spatial variations in cellular abundances and biomass of photosynthetic plankton, heterotrophic bacterial abundances varied <2-fold between distinct oceanic regions. Such data may support the hypothesis that the biomass and production of photosynthetic microorganisms, specifically Synechococcus and picoplanktonic eukaryotes, are more sensitive to regional variations in nutrient supply than heterotrophic bacterial biomass or planktonic respiratory activities.

One of the primary motivations for the present study was to better understand the spatial coupling in photosynthetic production and community respiration in the sea. We restricted our analyses to the well-lit, nearsurface waters; in general, we found that throughout the subtropical gyres where picoplankton dominated photosynthetic biomass, rates of GPP and R were low and comparable in magnitude. In contrast, in nearequatorial waters where larger phytoplankton were more numerous, rates of GPP were strongly decoupled from R. The resulting NCP of the subtropical gyres was statistically indistinguishable from zero, or slightly negative (net heterotrophic), while decoupling of GPP and $\mathrm{R}$ in the near-equatorial waters resulted in positive rates of $\mathrm{NCP}$ (with rates ranging from 0.60 to $3.00 \mu \mathrm{mol}$ $\mathrm{O}_{2} \mathrm{l}^{-1} \mathrm{~d}^{-1}$ ).

These results are consistent with previous studies that have examined regional variations in plankton metabolism in other regions of the world's oceans (Duarte et al. 2001, Serret et al. 2001, Arístegui \& Harrison 2002, Robinson et al. 2002, Serret et al. 2006, Morán et al. 2007, Gist et al. 2009), where net autotrophic conditions frequently prevail in regions where concentrations of $\mathrm{chl}$ a are relatively enriched and nutrients are actively supplied to the near-surface waters. In the subtropical Atlantic, Robinson et al. (2002) observed mixed layer rates of $\mathrm{R}$ ranging from 1.0 to $4.8 \mu \mathrm{mol} \mathrm{O} \mathrm{O}_{2} \mathrm{l}^{-1} \mathrm{~d}^{-1}$, while GPP ranged from 0.3 to $1.0 \mu \mathrm{mol} \mathrm{O} \mathrm{O}_{2}^{-1} \mathrm{~d}^{-1}$. In contrast, this same study reported rates of $\mathrm{R}$ in upwelling regions of the central Atlantic varying between 1.1 and $11.3 \mu \mathrm{mol} \mathrm{O} \mathrm{O}^{-1} \mathrm{~d}^{-1}$, while GPP was more variable, ranging between 1.9 and $30.2 \mu \mathrm{mol} \mathrm{O} \mathrm{I}^{-1} \mathrm{~d}^{-1}$. Juranek \& Quay (2010) utilized the oxygen isotope anomaly technique to derive high frequency estimates of GPP from cruises transect through the subtropical and tropical Pacific. These 
authors estimated that on average, mixed layer rates of GPP increased 2- to 3-fold in the equatorial waters compared the SPSG and NPSG. These same cruise transects were used in another study to derive estimates of NCP based on dissolved inorganic carbon pool ${ }^{13} \mathrm{C} /{ }^{12} \mathrm{C}$ mixed layer isotope ratios (Quay et al. 2009); these authors estimate that on average, NCP increased $\sim 2$-fold from the subtropics into the nearequatorial waters. Notably, these authors consistently observed positive NCP in all regions studied; the reasons underlying differences in the estimates of the net metabolic state of the ocean, derived from bottle $\mathrm{O}_{2}$ incubations versus such geochemical approaches, remain unknown but fundamental to our understanding of ocean carbon cycling.

As has been described for other areas of the world's oceans, we observed that regional differences in NCP were largely dictated by variations in GPP more so than R (Arístegui \& Harrison 2002, González et al. 2002, Agustí \& Duarte 2005). On average, we found that rates of GPP increased 3- to 4-fold between the subtropical gyres and equatorial waters, while rates of $\mathrm{R}$ in either region were generally varying $<2$-fold. In the subtropical North Atlantic, Serret et al. (2001, 2002) observed up to 4 -fold greater variability in rates of GPP relative to R. Similarly, in both oligotrophic and upwelling regions of the Atlantic Ocean, Arístegui \& Harrison (2002) concluded GPP was always more variable than $\mathrm{R}$, a finding these authors attribute to differences in the time and space scales over which these processes are coupled. Measurements of plankton metabolism conducted at a series of coastal sites along the western Antarctic shelf also revealed that rates of GPP and NCP tended to be more variable than R (Agusti et al. 2004). Moreover, these authors observed that GPP and NCP were positively related, while GPP and R were not, suggesting GPP was the predominant control on NCP. Consistent with these reports, we also found that in large regions of the low-nutrient subtropical gyres of the Pacific, rates of R and GPP were either balanced $(\mathrm{NCP}=0$ ) or slightly net heterotrophic, while active nutrient input to the well-lit upper ocean in the equatorial waters increased GPP and resulted in strongly positive NCP.

A number of studies have sought to identify factors controlling the balance of GPP and R in open ocean systems. In a recent meta-analysis of plankton metabolism measurements in various marine environments, Duarte \& Regaudie-de-Gioux (2009) found that the threshold rate of GPP required to achieve metabolic balance (GPP $=\mathrm{R}$ ) was widely variable among oceanic regions. Globally, this threshold averaged $1.09 \mu \mathrm{mol} \mathrm{O} \mathrm{O}_{2} \mathrm{l}^{-1} \mathrm{~d}^{-1}$, while the oligotrophic waters of the Pacific demonstrated some of the lowest thresholds of GPP $\left(0.84 \mu \mathrm{mol} \mathrm{O} \mathrm{O}^{-1} \mathrm{~d}^{-1}\right)$. Compilation of our measurements in both the nutrient-depleted subtropical gyres and relatively nutrient-enriched waters of the equatorial region indicated that at rates of GPP $<0.73 \mu \mathrm{mol} \mathrm{O} \mathrm{O}^{-1} \mathrm{~d}^{-1}, \mathrm{R}$ tended to balance or exceed GPP. González et al. (2002) and Gist et al. (2009) concluded that variability in GPP in oligotrophic regions of the North Atlantic was predominately controlled by variations in the supply of nutrients to the upper ocean. Similar conclusions were reached by McAndrew et al. (2007) based on a series of nutrient perturbation experiments conducted in the oligotrophic NPSG. These authors observed large increases in GPP with comparatively smaller changes in $\mathrm{R}$ following addition of nutrient-enriched deep sea water to upper ocean plankton assemblages.

Our data suggest that physical and biological processes supplying nutrients to the well-lit upper ocean form important controls on the magnitude of GPP. However, the results of the present study do not allow us to determine whether the uncoupling of GPP and R in the near-equatorial waters stemmed from increases in the net growth rates of photosynthetic microorganisms, or whether the observed increases in GPP reflected increases in the biomass of photosynthetic microorganisms. Various lines of evidence, including pigment determinations and flow cytometric characterizations of cell abundances and sizes, suggest phytoplankton biomass in the near-equatorial stations was elevated relative to the subtropical gyres. Concentrations of chl a increased by more than 6 -fold in the relatively nutrient-enriched near-equatorial waters, with larger, eukaryotic phytoplankton appearing increasingly abundant in these waters. Intriguingly, Chl a-normalized rates of GPP varied $\sim 4$-fold along the cruise transect, but these rates did not demonstrate significant regional variability; however, coinciding with increases in total chl $a$, the composition of the phytoplankton taxa also changed, making it difficult to determine whether changes in chl a provide an adequate proxy for assessing regional variations in phytoplankton biomass. Normalization of GPP to PC concentrations suggested that on a per unit biomass basis, the near-equatorial waters were as much as $~ 5$-fold more productive than the oligotrophic gyres.

There was also evidence suggesting that phytoplankton physiology varied markedly among the regions sampled in the present study. Flow cytometric determination of relative fluorescence and FLS indicated that populations of Prochlorococcus in the higher productivity waters near the equator were larger, and their relative fluorescence was brighter, than those found in the oligotrophic gyres. Similarly, Prochlorococcus cell-normalized concentrations of divinyl chl a increased in the equatorial waters, suggesting regional changes in the photophysiology of these picoplank- 
tonic assemblages. Such photophysiological changes might be indicative of spatial variability in photosynthetic plankton growth and hence alterations in rates of GPP.

Taken together, several prominent patterns emerge from our observations of plankton metabolism and biogeochemical variability in the Pacific Ocean. Rates of GPP tended to be greatest in those regions where plankton biomass was elevated, and larger celled, eukaryotic phytoplankton became increasingly abundant; these regions coincided with areas where nutrient concentrations were relatively enriched. In contrast to regional variations in photosynthetic microorganism biomass and production, rates of $\mathrm{R}$ and abundances (and presumably biomass) of heterotrophic bacteria were considerably less variable. As a result, throughout the equatorial waters where nutrients were actively supplied to the upper ocean, imbalances in GPP and R resulted in positive NCP. These data suggest latitudinal variations in nutrient supply influence the biomass and metabolism of photosynthetic plankton to a much greater degree than for heterotrophic microorganisms.

Heterotrophic bacteria can be major contributors to plankton community respiration (Robinson \& Williams 2005). The growth, biomass, and respiratory activities of these picoplankton appear controlled by a myriad of biotic and abiotic processes. Picoplankton-based food webs typically demonstrate weak oscillations in biomass, likely owing to strong top-down control of population sizes (Ducklow 1999). In contrast, population dynamics associated with the biomass of larger, photosynthetic plankton often appears strongly controlled by bottom-up processes, namely those influencing nutrient and light availability to the upper ocean. Such processes appear to permit expansion of phytoplankton biomass through disruption of trophodynamic equilibrium, for example decoupling of phytoplankton growth and removal. Our observations suggest that by modifying the structure and function of the phytoplankton food web, physical control of nutrient availability plays a key role in regulating GPP and R, and thus net fluxes of carbon and oxygen in large regions of the Pacific Ocean.

Acknowledgements. We thank the various scientists and staff who contributed to the CMORE BULA cruise. In particular, R. Bidigare, S. Curless, C. Mahaffey, A. Harlan, S. Christensen, B. Watkins, E. Grabowski, K. Doggett, and L. Fujieki provided sample analyses or logistical support for the project. The comments of 3 reviewers improved the manuscript. The Center for Microbial Oceanography: Research and Education (CMORE) provided support for this cruise. We also extend our gratitude to the officers and crew of RV 'Kilo Moana'. Funding for this study derived from the National Science Foundation (to M.J.C. and D.M.K.), with additional support from the Gordon and Betty Moore Foundation (to D.M.K.).

\section{LITERATURE CITED}

Acker JG, Leptoukh G (2007) Online analysis enhances use of NASA earth science data. EOS Trans AGU 88, doi: 10.1029/2007EO020003

Agustí S, Duarte CM (2005) Threshold of gross primary production for planktonic metabolic balance in the Southern Ocean: an experimental test. Limnol Oceanogr 50: 1334-1339

Agustí S, Satta MP, Mura MP (2004) Summer community respiration and pelagic metabolism in upper surface Antarctic waters. Aquat Microb Ecol 35:197-205

Arístegui J, Harrison WG (2002) Decoupling of primary production and community respiration in the ocean: implications for regional carbon studies. Aquat Microb Ecol 29: 199-209

Azam F, Fenchel T, Field JG, Gray JS, Meyer-Reil LA, Thingstad F (1983) The ecological role of water-column microbes in the sea. Mar Ecol Prog Ser 10:257-263

Bidigare RR, Van Heukelem L, Trees CC (2005) Analysis of algal pigments by high performance liquid chromatography. In: Andersen RA (ed) Algal culturing techniques. Elsevier Academic Press, San Diego, CA, p 327-346

Bouman HA, Ulloa O, Scanlan DJ, Zwirglmaier K and others (2006) Oceanographic basis of the global surface distribution of Prochlorococcus ecotypes. Science 312:918-921

Carlson CA, Ducklow HW, Michaels AF (1994) Annual flux of dissolved organic carbon from the euphotic zone in the northwestern Sargasso Sea. Nature 371:405-408

Carritt DE, Carpenter JH (1966) Comparison and evaluation of currently employed modifications of the Winkler method for determining dissolved oxygen in seawater; a NASCO report. J Mar Res 24:286-318

del Giorgio PA, Duarte CM (2002) Respiration in the open ocean. Nature 420:379-384

del Giorgio PA, Cole JJ, Cimbleris A (1997) Respiration rates in bacteria exceed phytoplankton production in unproductive aquatic systems. Nature 385:148-151

> Dore JE, Karl DM (1996) Nitrite distributions and dynamics at station ALOHA. Deep-Sea Res II 43:385-402

> Duarte CM, Agustí S (1998) The $\mathrm{CO}_{2}$ balance of unproductive aquatic ecosystems. Science 281:234-236

> Duarte CM, Cebrian J (1996) The fate of marine autotrophic production. Limnol Oceanogr 41:1758-1766

Duarte CM, Regaudie-de-Gioux A (2009) Thresholds of gross primary production for the metabolic balance of marine planktonic communities. Limnol Oceanogr 54:1015-1022

> Duarte MC, Agustí S, Arístegui J, González N, Anadon R (2001) Evidence for a heterotrophic subtropical northeast Atlantic. Limnol Oceanogr 46:425-428

Ducklow HW (1999) The bacterial component of the oceanic euphotic zone. FEMS Microbiol Ecol 30:1-10

Emerson S, Quay P, Karl D, Winn C, Tupas L, Landry M (1997) Experimental determination of the organic carbon flux from open-ocean surface waters. Nature 389:951-954

Emerson S, Stump C, Johnson B, Karl DM (2002) In situ determination of oxygen and nitrogen dynamics in the upper ocean. Deep-Sea Res I 49:941-952

Falkowski PG (1994) The role of phytoplankton photosynthesis in global biogeochemical cycles. Photosynth Res 39: 235-258

Falkowski PG, Fenchel T, Delong EF (2008) The microbial engines that drive Earth's biogeochemical cycles. Science 320:1034-1039

Field CB, Behrenfeld MJ, Randerson JT, Falkowski P (1998) Primary production of the biosphere: integrating terrestrial and oceanic components. Science 281:237-240 
Garside C (1982) A chemi-luminescent technique for the determination of nanomolar concentrations of nitrate and nitrite in sea-water. Mar Chem 11:159-167

Gist N, Serret P, Woodward EMS, Chamberlain K, Robinson C (2009) Seasonal and spatial variability in plankton production and respiration in the Subtropical Gyres of the Atlantic Ocean. Deep-Sea Res II 56:931-940

Goldman JC (1988) Spatial and temporal discontinuities of biological processes in pelagic surface waters. In: Rothschild BJ (ed) Towards a theory on biological and physical processes in the world ocean. Kluwer Academic Publishers, Dordrecht, p 273-296

Goldman JC, McCarthy JJ, Peavey DG (1979) Growth rate influence on the chemical composition of phytoplankton in oceanic waters. Nature 279:210-215

> González N, Anadón R, Marañón E (2002) Large-scale variability of planktonic net community metabolism in the Atlantic Ocean: importance of temporal changes in oligotrophic subtropical waters. Mar Ecol Prog Ser 233:21-30

Hewson I, Paerl RW, Tripp HJ, Zehr JP, Karl DM (2009) Metagenomic potential of microbial assemblages in the surface waters of the central Pacific Ocean tracks variability in oceanic habitat. Limnol Oceanogr 54:1981-1994

Hickman AE, Dutkiewicz S, Williams RG, Follows MJ (2010) Modeling the effects of chromatic adaptation on phytoplankton community structure in the oligotrophic ocean. Mar Ecol Prog Ser 406:1-17

Jenkins WJ, Goldman JC (1985) Seasonal oxygen cycling and primary production in the Sargasso Sea. J Mar Res 43: 465-491

Johnson ZI, Zinser ER, Coe A, McNulty NP, Woodward EMS, Chisholm SW (2006) Niche partitioning among Prochlorococcus ecotypes along ocean-scale environmental gradients. Science 311:1737-1740

Juranek LW, Quay PD (2010) Basin-wide photosynthetic production rates in the subtropical and tropical Pacific Ocean determined from dissolved oxygen isotope ratio measurements. Global Biogeochem Cycles 24:GB2006 doi: 10.1029/ 2009GB003492

Karl DM, Holm-Hansen O (1978) Methodology and measurement of adenylate energy charge ratios in environmental samples. Mar Biol 48:185-197

Karl DM, Tien G (1992) MAGIC: a sensitive and precise method for measuring dissolved phosphorus in aquatic environments. Limnol Oceanogr 37:105-116

Karl DM, Laws EA, Morris P, Williams PJleB, Emerson S (2003) Global carbon cycle (communication arising): metabolic balance of the open sea. Nature 426:32

Laws EA, Ditullio GR, Redalje DG (1987) High phytoplankton growth and production rates in the North Pacific Subtropical Gyre. Limnol Oceanogr 32:905-918

Editorial responsibility: Craig Carlson, Santa Barbara, California, USA
Luz B, Barkan E (2000) Assessment of oceanic productivity with the triple-isotope composition of dissolved oxygen. Science 288:2028-2031

> Marañón E (2005) Phytoplankton growth rates in the Atlantic subtropical gyres. Limnol Oceanogr 50:299-310

McAndrew PM, Björkman KM, Church MJ, Morris PJ, Jachowski N, Williams PJleB, Karl DM (2007) Metabolic response of oligotrophic plankton communities to deep water nutrient enrichment. Mar Ecol Prog Ser 332:63-75

Michaels AF, Bates NR, Buesseler KO, Carlson CA, Knap AH (1994) Carbon-cycle imbalances in the Sargasso Sea. Nature 372:537-540

Morán XAG, Perez V, Fernandez E (2007) Mismatch between community respiration and the contribution of heterotrophic bacteria in the NE Atlantic open ocean: What causes high respiration in oligotrophic waters? J Mar Res 65: 545-560

Quay PD, Stutsman J, Feely RA, Juranek LW (2009) Net community production rates across the subtropical and equatorial Pacific Ocean estimated from air-sea $\delta^{13} \mathrm{C}$ disequilibrium. Global Bigeochem Cycles 23:GB2006 doi: 10.1029/2008GB003193

> Riser SC, Johnson KS (2008) Net production of oxygen in the subtropical ocean. Nature 451:323-325

Robinson C Williams PJleB (2005) Respiration and its measurement in surface marine waters. In: Williams PJleB, del Giorgia PA (eds) Respiration in aquatic ecosystems. Oxford University Press, Oxford, p 147-180

Robinson C, Serret P, Tilstone G, Teira E, Zubkov MV, Rees AP, Woodward EMS (2002) Plankton respiration in the eastern Atlantic Ocean. Deep-Sea Res I 49:787-813

> Serret P, Robinson C, Fernandez E, Teira E, Tilstone G (2001) Latitudinal variation of the balance between plankton photosynthesis and respiration in the eastern Atlantic Ocean. Limnol Oceanogr 46:1642-1652

> Serret P, Fernández E, Robinson C (2002) Biogeographic differences in the net ecosystem metabolism of the open ocean. Ecology 83:3225-3234

> Serret P, Fernández E, Robinson C, Woodward EMS, Pérez V (2006) Local production does not control the balance between plankton photosynthesis and respiration in the open Atlantic Ocean. Deep-Sea Res II 53:1611-1628

Siegenthaler U, Sarmiento JL (1993) Atmospheric carbon dioxide and the ocean. Nature 365:119-125

Strickland JD, Parsons TR (1972) A practical handbook of seawater analysis. Fisheries Research Board of Canada, Ottawa, ON

Williams PJleB, Morris PJ, Karl DM (2004) Net community production and metabolic balance at the oligotrophic site, station ALOHA. Deep-Sea Res I 51:1563-1578

Submitted: March 18, 2010; Accepted: August 24, 2010 Proofs received from author(s): October 25, 2010 